\section{Faktor-Faktor Yang Mempengaruhi Harga Saham Dengan Kebijakan Dividen Sebagai Pemoderasi Pada Perusahaan LQ45 Di BEI Tahun 2015-2017}

Stocks Price and Dividend Policy in LQ45 Companies

\author{
Parmuji, Maulana Malik Ibrahim, Syahril Djaddang \\ ${ }^{123^{2}}$ Sekolah Tinggi Ilmu Ekonomi Hidayatullah, Depok, Indonesia \\ Email :parmuji@stiehidayatullah.ac.id
}

\section{ABSTRACT}

The stock price is an important point to be considered by investors, there are many factors that can affect the stock price, one of which is the fundamental factor. This study examines the effect of Return on Assets (ROA), Current Ratio (CR) and Debt to Equity Ratio (DER), as well as Dividend Payout Ratio (DPR) as a moderator on stock prices in Indonesia in 2015-2017. The sampling technique used was purposive sampling. The data of this study consisted of companies listed on the Indonesian Stock Exchange (IDX) for 3 years of observation, a total of 66 sample data. The test was carried out using SPSS 22. The test results show that ROA does not affect stock prices. CR affects the stock price. DER does not affect share prices. DPR was found unable to moderate the effect of $R O A$ on stock prices, while DPR was able to moderate the effect of $C R$ on stock prices. and the DPR was unable to moderate the effect of DER on share prices

Keywords: Return on Asset; Current Ratio; Debt to Equity Ratio; Dividen Payout Ratio; Harga Saham

\begin{abstract}
ABSTRAK
Harga saham merupakan poin penting diperhatikan oleh para investor, banyaknya faktor yang dapat mempengaruhi harga saham salah satunya faktor fundamental. Penelitian ini menguji pengaruh Return on Asset (ROA), Current Ratio (CR) dan Debt to Equity Ratio (DER), serta Dividen Payout Ratio (DPR) sebagai pemoderasi terhadap harga saham di Indonesia tahun 2015-2017. Teknik sampling yang digunakan adalah purposive sampling. Data penelitian ini terdiri dari perusahaan yang listing di Indonesian Stock Exchange (IDX) selama 3 tahun pengamatan, total sebanyak 66 data sample. Pengujian dilakukan dengan menggunakan SPSS 22. Hasil pengujian menunjukan ROA tidak mempengaruhi harga saham. CR mempengaruhi harga saham. DER tidak mempengaruhi harga saham. DPR ditemukan tidak mampu memoderasi pengaruh ROA tehadap harga saham, sedangkan DPR mampu memoderasi pengaruh CR terhadap harga saham. dan DPR tidak mampu memoderasi pengaruh DER terhadap harga saham.
\end{abstract}

Kata Kunci: Return on Asset; Current Ratio; Debt to Equity Ratio; Dividen Payout Ratio; Harga Saham

\section{PENDAHULUAN}

Setiap perusahaan memiliki visi dan misi untuk mencapai tujuannya kedua tujuan tersebut haruslah bisa saling mendukung dan melengkapi. Bagi perusahaan yang berorientasi pada keuntungan akan memfokuskan kegiatan operasionalnya untuk memaksimalkan tingkat laba. Peningkatan laba memungkinkan peningkatan kesejahteraan para pemegang saham melalui pembagian dividend. Tingkat laba yang baik dan berkelanjutan juga akan menciptakan persepsi baik dari masyarakat akan keadaan
Submitted: MARET 2021

Accepted: APRIL 2021

\section{JIMKES}

Jurnal Ilmiah Manajemen Kesatuan Vol. 9 No. 1, 2021 pp. $141-150$ IBI Kesatuan
ISSN $2337-7860$ E-ISSN $2721-169 \mathrm{X}$ 
Stocks Price and Dividend Policy in LQ45 Companies

142 perusahaan tersebut, sehingga dapat memunculkan investor-investor baru potensial yang tertarik memiliki saham perusahaan tersebut. Semakin baik nilai perusahaan akan meningkatkan nilai harga saham, return yang dibagikan kepada investor berupa kenaikan capital gain dan pembagian dividend. Dari sini kita dapat menyimpulkan bahwa penilaian pasar merupakan bentuk persepsi investor saat ini dan waktu akan datang terhadap tingkat keberhasilan perusahaan dalam mencapai tujuannya.

Salah satu sarana bagi para investor menilai perusahaan adalah melalui laporan keuangan yang dibuat perusahaan tersebut. Analisa laporan keuangan dilakukan agar didapat keterkaitan angka-angka dan trend dari angka-angka tersebut dalam beberapa periode sehingga mampu memperkirakan keadaan atau kejadian di waktu mendatang. Horne et,al (2005:234) berpendapat rasio keuangan merupakan sarana yang digunakan untuk menganalisa kondisi keuangan dan kinerja perusahaan. Kita menghitung berbagai rasio karena dengan cara ini kita bisa mendapat perbandingan yang mungkin akan berguna daripada berbagai angka mentahnya sendiri. Harga saham merupakan indikator atas performance perusahaan yang penting untuk dipantau oleh para stakeholder sebagai dasar pembuatan keputusan ekonomi yang dapat mempengaruhi operasionalisasi perusahaan. Adanya volatility saham dari tahun 2015-2017 terhadap closing price pada Index LQ45 memotivasi Peneliti untuk melakukan penelitian.

Tabel 1 Pergerakan Harga Saham

Sumber: Idx (data diolah)

\begin{tabular}{|c|c|c|c|}
\hline Indeks & 2015 & 2016 & 2017 \\
\hline LQ45 & 8.171 & 8.456 & 8.832 \\
\hline
\end{tabular}

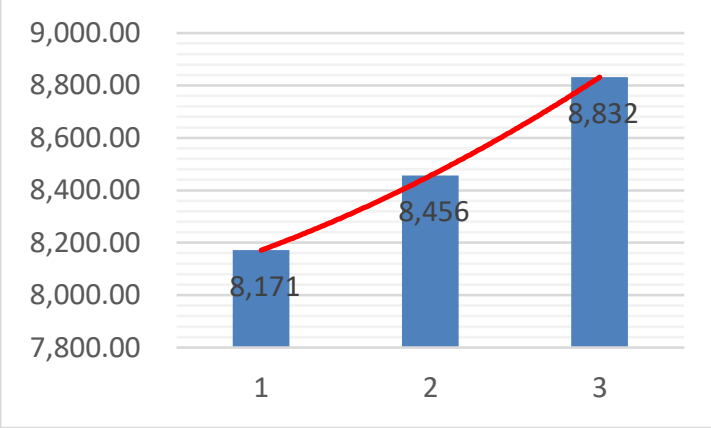

Gambar 1 Closing Price Index LQ45

Telah banyak penelitian yang dilakukan mengenai harga saham dengan variabel yang bermacam-macam seperti ROA, ROE, NPM, DAR, DER, EPS, PER, PBV, Cash Ratio, CR, dan lainnya. Penulis mengambil Return on Asset (ROA), Current Ratio (CR) dan Debt to Equity Ratio (DER), serta Dividen Payout Ratio (DPR) sebagai variable pemoderasi dan bagaimana pengaruhnya terhadap harga saham yang masuk dalam Top Index LQ45 di Indonesia.

Current Ratio menunjukkan kemampuan perusahaan dalam membayar hutang jangka pendek atau yang segera jatuh tempo (Gibson, 2013:243). Indikator digunakan para supplier dan vendor untuk menganalisis kredit mereka. Kahfi et,al.(2018) dan Sondakh et, al. (2015) menemukan pengaruh positif dan signifikan atas current ratio terhadap harga saham. Hasil yang berbeda didapatkan oleh Aryani et,al (2018) menemukan bahwa Current Ratio tidak berpengaruh signifikan terhadap harga saham. Debt to Equity Ratio alat menganalisa kemampuan agen dalam mengelola hutang. Ariyani et,al. (2018), menemukan korelasi negatif signifikan pada DER dengan harga saham. Korelasi negatif mengindikasikan bahwa institusi tidak mampu mengendalikan kewajiban pembayaran hutang-hutangnya sehingga hal tersebut mengirimkan sinyal negatif yang mengakibatkan penurunan kepercayaan publik yang akhirnya menurunkan harga saham. Hasil yang berbeda didapatkan dari penelitian yang dilakukan oleh Rahmawati (2017) yang menemukan pengaruh positif signifikan atas DER terhadap harga saham, selama perusahaan dapat menyeimbangkan biaya dan manfaat atas penambahan hutang, maka penambahan dana akan dapat membantu pembiayaan 
operasional. Berbeda halnya dengan hasil penelitian yang ditunjukkan oleh Marinda (2017), yang menunjukkan bahwa DER tidak berpengaruh signifikan terhadap harga saham.

Munawaroh dan Priyadi (2014) mengungkapkan beragamnya respon yang dimiliki investor terhadap infomasi keuangan yang dipublikasikan hal ini disebabkan oleh adanya asimeteri informasi. Informasi yang relevan, tepat waktu, tidak bias, serta berisi data-data mengenai keadaan masa lalu, kini maupun masa depan baik berupa catatan maupun gambaran sangat diperlukan investor dalam melakukan pertimbangan pembuatan keputusan investasi serta prospek perusahaan. Informasi-informasi tersebut memberikan sinyal. Ditandai dengan adanya asosiasi antara peristiwa dengan return, harga atau volume saham di pasar modal. Signaling theory adalah tindakan manajemen yang memberikan petunjuk bagi investor dan stakeholders lain mengenai bagaimana manajemen memandang prospek perusahaan (Brigham dan Ehrhardt, 2011). Laporan posisi keuangan merupakan ringkasan dari kebijakan manajemen di masa lalu, yang diwakilkan oleh rasio-rasio keuangan perusahaan, sedangkan catatan atas laporan keuangan merupakan gambaran tindakan yang akan dilakukan saat ini dan akan datang. Perusahaan yang berprospek baik cenderung untuk memberikan sinyal informasi yang positif kepada para stakeholder dengan harapan harga saham akan meningkat sebagai respon dari pasar dan sebaliknya.

Penelitian mengenai pengaruh profitabilitas terhadap harga saham yang diteliti oleh Darnita (2014), yang menemukan hasil bahwa secara simultan bahwa profitabilitas yang diproksikan dengan ROA, ROE, NPM, dan EPS secara simultan berpengaruh positif signifikan terhadap harga saham. Koefisien positif menunjukkan bahwa semakin besar margin yang diperoleh perusahaan maka harga saham akan meningkat. Penemuan bukti empiris pada penelitian lainnya diantaranya Ismail (2017), Sondakh et,al. (2015), Zuliarni (2012). Pengaruh profitabilitas dengan harga saham berdasarkan literature dan penelitian empiris terdahulu yang diaplikasikan dalam penelitian ini diasumsikan positif. Hal tersebut dapat diartikan, jika suatu perusahaan mengalami kenaikan return on assets maka dapat diprediksi investor akan semakin tertarik untuk berinvestasi sehingga akan meningkatkan permintaan saham yang berakibat harga saham juga akan mengalami kenaikan.

Penelitian mengenai pengaruh kebijakan hutang terhadap harga saham yang diteliti oleh Kahfi et,al.(2018), Sondakh et, al. (2015), Rahmawati (2017) dan Martini dan Riharjo (2014), yang menemukan hasil bahwa kebijakan hutang berpengaruh positif dan signifikan. Sondakh et,al. (2015) menyatakan bahwa penambahan hutang sampai dengan titik tertentu dapat digunakan untuk pengembangan bisnis, hal ini kemudian akan meningkatkan harga saham. Pengaruh kebijakan hutang dengan harga saham berdasarkan literature dan penelitian empiris terdahulu yang diaplikasikan dalam penelitian ini diasumsikan positif. Hal tersebut dapat diartikan, jika suatu perusahaan mengalami kenaikan rasio hutang sampai dengan titik tertentu, akan menimbulkan sinyal bahwa perusahaan sedang dalam keadaaan baik sehingga berdampak terhadap meningkatnya harga saham.

Tujuan dari penelitian ini adalah sebagai berikut: 1) Untuk menganalisa pengaruh ROA terhadap harga saham 2) Untuk menganalisa pengaruh $C R$ terhadap harga saham 3) Untuk menganalisa pengaruh DER terhadap harga saham 4) Untuk menganalisa kemampuan DPR dalam memoderasi ROA terhadap harga saham 5) Untuk menganalisa kemampuan DPR dalam memoderasi CR terhadap harga saham 6) Untuk menganalisa kemampuan DPR dalam memoderasi DER terhadap harga saham.

\section{METODE PENELITIAN}

Penelitian ini bertujuan untuk memperoleh bukti empiris pengaruh ROA, CR dan DER terhadap harga saham dengan DPR sebagai variabel pemoderasi pada perusahaan yang masuk ke dalam index LQ45 tahun 2015-2017 berturut-turut. Analisis data dalam penelitian ini menggunakan SPSS 22 untuk melakukan analsisi regresi berganda.
Stocks Price and Dividend Policy in LQ45 Companies

143 
Stocks Price and Dividend Policy in LQ45 Companies

144

Pemilihan sample dilakukan dengan metode purposive sampling yang telah ditetapkan kriteria-kriterianya.

\section{Hipotesis Penelitian}

$\mathrm{H}_{1}$ : ROA berpengaruh signifikan terhadap harga saham;

$\mathrm{H}_{2}$ : $\quad$ CR berpengaruh signifikan terhadap harga saham;

$\mathrm{H}_{3}$ : DER berpengaruh signifikan terhadap harga saham;

$\mathrm{H}_{4}$ : DPR dapat memoderasi pengaruh ROA terhadap harga saham;

$\mathrm{H}_{5}$ : DPR dapat memoderasi pengaruh CR terhadap harga saham;

$\mathrm{H}_{6}$ : DPR dapat memoderasi pengaruh DER terhadap harga saham;

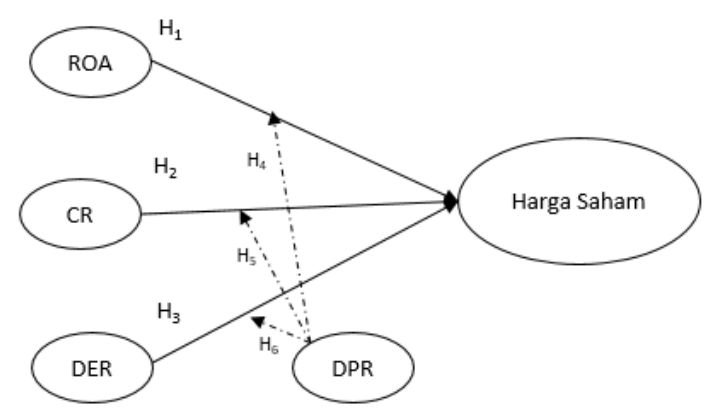

Gambar 2 Kerangka Pemikiran

\section{HASIL DAN PEMBAHASAN}

Analisis Statistik Deskriptif

Analisa statistik deskriptif memberikan gambaran karakteristik data variabel penelitian. Deksriptif dalam penelitian ini terdiri atas 66 data, dengan nilai minimum, maksimum, mean, dan standard deviasi disajikan dalam tabel 2.

Tabel 2 Hasil Statistik Deskriptif

\begin{tabular}{|l|r|r|r|r|r|}
\hline \multicolumn{1}{|c|}{ Keterangan } & N & \multicolumn{1}{c|}{ Min } & \multicolumn{1}{c|}{ Max } & \multicolumn{1}{c|}{ Mean } & $\begin{array}{c}\text { Std. } \\
\text { Deviation }\end{array}$ \\
\hline ROA & 66 & -4.75 & 16.24 & 6.19 & 4.30 \\
CR & 66 & 48.16 & 545.48 & 219.71 & 123.22 \\
DER & 66 & .18 & 2.66 & .96 & .62 \\
DPR & 66 & .00 & 88.40 & 23.84 & 21.75 \\
HARGA SAHAM & 66 & 131.00 & 17032.00 & 3861.56 & 3781.72 \\
Valid N (listwise) & 66 & & & & \\
\hline
\end{tabular}

Sumber: data diolah

\section{Pengujian Normalitas}

Pengujian ini dilakukan dengan uji Kolmogorov Smirnov dan Probability Plot (P-Plot). Terdapat kriteria dalam pengujian Kolmogorov Smirnov yaitu nilai signifikansinya $>0.05$. sedangkan uji P-Plot menurut Imam Ghazali (2011: 161) model regresi dikatakan berdistribusi normal jika data ploting (titik-titik) yang menggambarkan data sesuangguhnya mengikuti garis diagonal. Hasil dari pengujian Kolmogorov Smirnov sesuai tabel 3. Berdasarkan hasil pengujian, didapatkan bahwa nilai asymp. Sig. (2-tailed) adalah sebesar 0.20. Hal ini berarti data berdistribusi normal $(>0.05)$ dan hasil dari pengujian $p$ plot. Berdasarkan hasil tersebut titik-titik berada pada sekitar dan mengikuti garis diagonal. Hal ini berarti menunjukkan juga data berdistribusi normal.

\section{Pengujian Multikolinearitas}

Menurut Imam Ghazali (2011: 107-108) model regresi dikatakan tidak mengalami gejala multikolinearitas jika nilai tolerance $>0.100$ dan nilai VIF $<10.00$. Sesuai tabel 4.3 di atas terlihat bahwa angka pada kolom tolerance ada pada range $0.197-0.669$ dan angka pada kolom VIF ada pada range 1.494 - 5.086, hal ini menunjukan bahwa model tidak mengalami gejala multikolinearitas. 
Tabel 3 Hasil Uji Normalitas Data

One-Sample Kolmogorov-Smirnov Test

\begin{tabular}{|ll|r|}
\hline & & $\begin{array}{c}\text { Unstandardized } \\
\text { Residual }\end{array}$ \\
\hline $\mathrm{N}$ & Mean & 66 \\
Normal Parameters, & .0000000 \\
& Std. Deviation & 3086.98514329 \\
Most Extreme Differences & Absolute & .067 \\
& Positive & .067 \\
& Negative & -.050 \\
Test Statistic & & .067 \\
Asymp. Sig. (2-tailed) & & $.200^{\mathrm{c}, \mathrm{d}}$ \\
\hline
\end{tabular}

Test distribution is Normal.

Sumber: Data diolah

Normal P.P Plot of Regression Standardized Residual

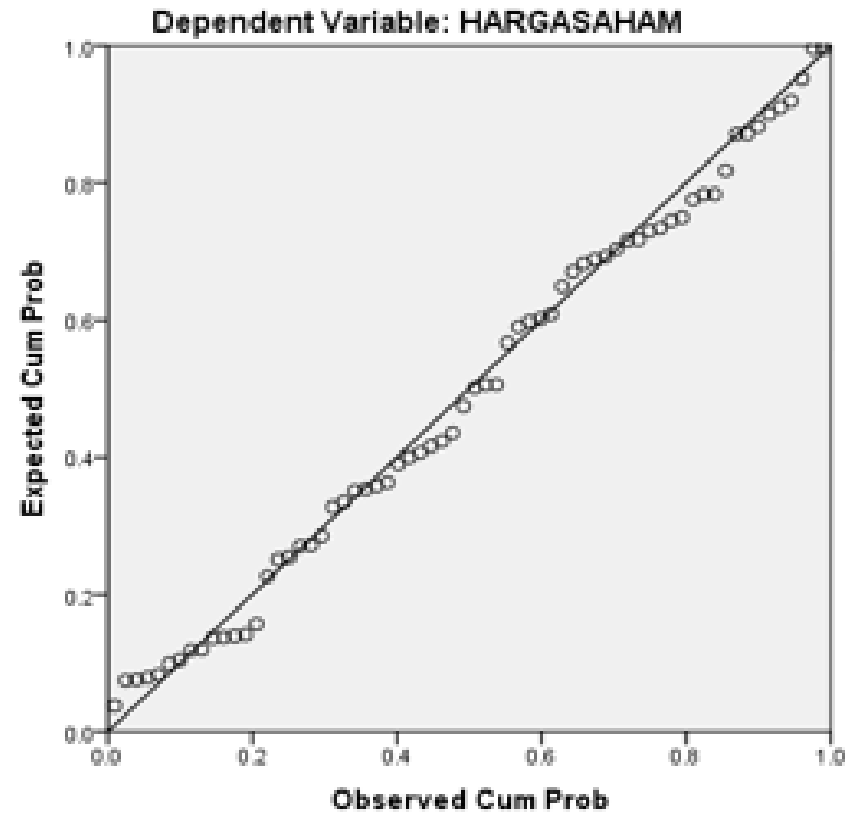

Gambar 3 Hasil Uji Normalitas

Tabel 3 Hasil Uji Multikolinearitas Data

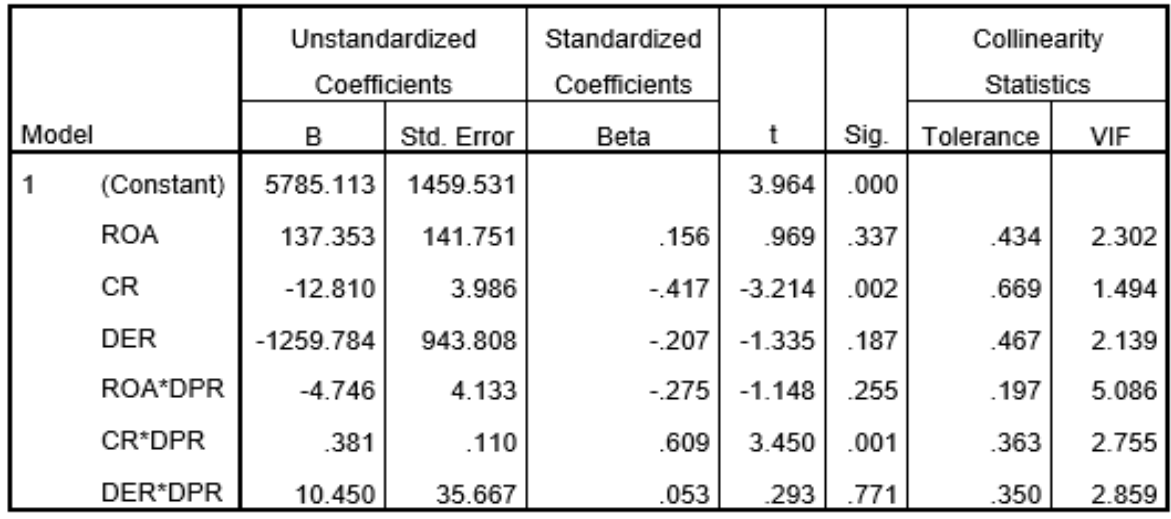

a. Dependent Variable: HARGASAHAM 
Stocks Price and Dividend Policy in LQ45 Companies

\section{Pengujian Heteroskedastisitas}

Pengujian bisa dengan melihat hasil uji Scatter Plots. Menurut Imam Ghazali (2011: 139) tidak terjadi heteroskedastisitas jika tidak ada pola yang jelas (bergelombang, melebar kemudian menyempit) pada gambar scatterplots, serta titik-titik menyebar di atas dan di bawah angka 0 pada sumbu Y. Hasil uji scatterplots dari model ini bisa dilihat pada gambar di bawah ini:

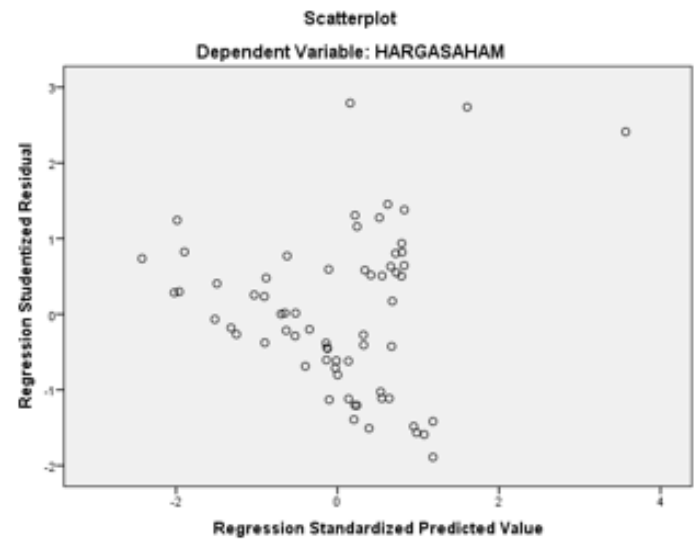

Gambar 4 Scatter Plot

Pada scatterplots di atas terlihat bahwa titik-titik terletak tidak mengikuti pola tertentu tetapi menyebar sehingga bisa disimpulkan bahwa model penelitian tidak terjadi heteroskedastisitas.

\section{Pengujian Autokorelasi}

Pengujian autokorelasi bisa menggunakan alat uji Durbin Watson dimana menurut Imam Ghazali (2011: 111) tidak ada gejala autokorelasi jika nilai Durbin Watson terletak antara nilai dU sampai 4-dU. Nilai dU dicari oada distribusi nilai tabel Durbin Watson berdasarkan nilai $\mathrm{K}$ dan $\mathrm{N}$ dengan signifikasi 5\%. Pada tabel Durbin Watson dengan signifikasi $5 \%$ untuk $\mathrm{K}=6$ dan $\mathrm{N}=66$ memiliki nilai dU sebesar 1,8041, maka nilai 4dU adalah sebesar 2,1959. Dan berdasarkan hasil pengujian pada tabel model summary adalah sebagai berikut:

Tabel 4 Model Summary

\begin{tabular}{|l|r|r|r|c|r|}
\hline Model & R & R Square & $\begin{array}{c}\text { Adjusted R } \\
\text { Square }\end{array}$ & $\begin{array}{c}\text { Std. Error of the } \\
\text { Estimate }\end{array}$ & Durbin-Watson \\
\hline 1 & $.578^{\mathrm{a}}$ & .334 & .266 & 3240.15072 & 1.986 \\
\hline
\end{tabular}

a. Predictors: (Constant), DER*DPR, ROA, CR, DER, CR*DPR, ROA*DPR

b. Dependent Variable: HARGASAHAM

Dari tabel di atas dapat disimpulkan bahwa model penelitian tidak mengalami gejala autokorelasi karena nilai Durbin-Watson sebesar 1,986 berada di antara nilai dU $(1,8041)$ dan 4-dU (2,1959).

Hasil uji Regresi berikut:

Berdasarkan hasil uji regresi pada tabel 4.4 di atas dapat dibuat model regresi sebagai Harga Saham $=5.785,11+137,35 \mathrm{ROA}-12,81 \mathrm{CR}-1.259,78 \mathrm{DER}-4,75 \mathrm{ROA}$ *DPR $+0.38 \mathrm{CR}^{*} \mathrm{DPR}+10.45 \mathrm{DER} * \mathrm{DPR}$

\section{Hasil Uji Koefisien Determinan $\mathbf{R}^{2}$}

Nilai $\mathrm{R}^{2}$ mengindikasikan seberapa besar kemampuan variabel eksogen (independen) dapat menjelaskan variabel endogen (dependen). Pada penelitian ini didapat $\mathrm{R}^{2}$ sebesar 33\% (sesuai tabel 4.4), hal tersebut dapat disimpulkan bahwa variabel ROA, CR dan DER dengan moderasi DPR bisa menjelaskan lebih 33\% harga saham, sedangkan sisanya sebesar $67 \%$ ditentukan oleh variabel lain diluar penelitian.

\section{Pengujian Hipotesis Pertama}

Berdasarkan hasil penelitian, variabel profitabilitas terbukti tidak berpengaruh terhadap harga saham. Koefisien positif mengindikasikan bahwa pengaruh ROA adalah 
searah terhadap harga saham. Hal ini berarti informasi keuntungan yang diperoleh perusahaan dengan perbandingannya terhadap total aset tidak menjadi pertimbangan utama investor dalam keputusan berinvestasi, hasil penelitian malah menunjukkan terjadi penurunan harga saham setiap adanya kenaikan ROA.

Hal ini bertentangan dengan hipotesa dan signaling theory yang telah dipaparkan sebelumnya dimana seharusnya ROA berpengaruh positif dan signifikan terhadap harga saham. Hasil dalam penelitian ini, bukan berarti menentang teori yang ada, namun bisa jadi dikarenakan penelitian ini hanya menggunakan 66 data sebagai sampel, bukan seluruh perusahaan yang menjual saham di bursa saham maka penelitian tidak dapat menampilkan pengaruh positif ROA secara keseluruhan. Hal ini juga mungkin dikarenakan pengaruh pasar dan perekonomian pada masa penelitian.

Tabel 5 Hasil Uji Regresi

\begin{tabular}{|c|c|c|c|c|c|c|c|}
\hline \multirow[b]{2}{*}{ Model } & \multicolumn{2}{|c|}{$\begin{array}{c}\text { Unstandardized } \\
\text { Coefficients }\end{array}$} & \multirow{2}{*}{$\begin{array}{c}\text { Standardized } \\
\text { Coefficients }\end{array}$} & \multirow[b]{2}{*}{$\mathrm{t}$} & \multirow[b]{2}{*}{ Sig. } & \multicolumn{2}{|c|}{ Collinearity Statistics } \\
\hline & B & Std. Error & & & & Tolerance & VIF \\
\hline 1 (Constant) & 5785.113 & 1459.531 & & 3.964 & .000 & & \\
\hline ROA & 137.353 & 141.751 & .156 & .969 & .337 & .434 & 2.302 \\
\hline CR & -12.810 & 3.986 & -.417 & -3.214 & .002 & .669 & 1.494 \\
\hline DER & -1259.784 & 943.808 & -.207 & -1.335 & .187 & -467 & 2.139 \\
\hline $\mathrm{ROA} \mathrm{A}^{*} \mathrm{DPR}$ & -4.746 & 4.133 & -.275 & -1.148 & .255 & 197 & 5.086 \\
\hline $\mathrm{CR}^{*} \mathrm{DPR}$ & .381 & 110 & .609 & 3.450 & .001 & .363 & 2.755 \\
\hline DER*DPR & 10.450 & 35.667 & .053 & .293 & .771 & .350 & 2.859 \\
\hline
\end{tabular}

a. Dependent Variable: HARGASAHAM

\section{Pengujian Hipotesis Kedua}

Berdasarkan hasil penelitian, variabel CR terbukti berpengaruh terhadap harga saham. Koefisien negatif mengindikasikan bahwa perusahaan-perusahaan masih belum memiliki kemampuan untuk menyeimbangkan manfaat dan biaya yang ditimbulkan dari hutang sehingga penambahan hutang cenderung menurunkan harga saham, walaupun pengaruhnya tidak signifikan. Hasil ini sesuai dengan trade-off theory, penambahan hutang akan meningkatkan risiko kebangkrutan apabila efek bunga (biaya) lebih besar dibanding manfaat penambahan deductible expense yang timbul akibat bunga. Hasil penelitian ini sejalan dengan hasil penelitian Ariyani et,al (2018), Meythi et,al (2011), dan Marinda (2017).

\section{Pengujian Hipotesis Ketiga}

Berdasarkan hasil penelitian, variabel DER terbukti tidak berpengaruh terhadap harga saham. Koefisien negatif mengindikasikan bahwa kenaikan Debt to Equity Ratio akan menurunkan harga saham dimasa datang. Hasil penelitian ini sejalan dengan hasil penelitian Sindu Priyo (2011). Menurut Sindu Priyo (2011), DER tidak menjadi atau sebagai pertimbangan investor dalam menentukan investasinya. Hal ini dikarenakan rasio tersebut tidak memberikan invormasi kepada investor apakah kinerja perusahaan tersebut baik atau buruk. Jika hutang perusahaan tersebut banyak belum tentu kinerja perusahaan jelek.

\section{Pengujian Hipotesis Keempat}

Berdasarkan hasil penelitian, variabel ROA terhadap harga saham dengan kebijakan dividen sebagai pemoderasi terbukti tidak berpengaruh terhadap harga saham. Koefisien negatif mengindikasikan bahwa adanya DPR justru melemahkan pengaruh ROA terhadap harga saham. Peningkatan ROA dengan diringi dengan pembagian dividen menyebabkan penurunan yang sangat signifikan terhadap harga saham. Hal ini sesuai dengan teori dari Brigham dan Houston (1999) dalam Asmirantho dan Yuliawati (2015), walaupun tingkat profitabilitas perusahaan tinggi namun adanya pembagian dividen
Stocks Price and dividend Policy in LQ45 Companies 
Stocks Price and Dividend Policy in LQ45 Companies

148 justru akan membuat laba ditahan mengecil sehingga tingkat pertumbuhan pendapatan terhambat dan harga saham akan turun signifikan.

\section{Pengujian Hipotesis Kelima}

Berdasarkan hasil penelitian, variabel CR terhadap harga saham dengan DPR sebagai pemoderasi terbukti berpengaruh positif terhadap harga saham. Koefisien positif mengindikasikan bahwa adanya DPR akan memperkuat pengaruh CR terhadap harga saham. Penambahan hutang yang diiringi dengan pembagian dividen menyebabkan kenaikan harga saham, hal ini disebabkan ketertarikan investor meningkat yang akhirnya akan menaikkan harga saham.

\section{Pengujian Hipotesis Keenam}

Berdasarkan hasil penelitian, variabel DER terhadap harga saham dengan DPR sebagai pemoderasi terbukti tidak berpengaruh terhadap harga saham. Koefisien positif mengindikasikan bahwa adanya DPR akan mempengaruhi hubungan DER terhadap harga saham. Penambahan hutang yang diiringi dengan pembagian dividen menyebabkan kenaikan harga saham, hal ini disebabkan ketertarikan investor meningkat yang akhirnya akan menaikkan harga saham.

\section{PENUTUP}

Adapun simpulan dari interpretasi hasil penelitian ini adalah sebagai berikut:

1. ROA tidak berpengaruh terhadap harga saham. Rasio ROA tidak mempengaruhi penilaian investor dalam mengapresiasi kinerja perusahaan sehingga tidak mempengaruhi harga saham.

2. Kebijakan hutang yang diproksikan dengan variabel CR dan DER berkorelasi negative. CR dapat mempengaruhi harga saham sedangkan DER tidak berpengaruh terhadap harga saham. Tingkat hutang yang tinggi, dapat menurunkan ketertarikan investor sehingga menurunkan permintaan saham dan akhirnya menyebabkan penurunan harga saham.

3. DPR tidak mampu memoderasi pengaruh profitabilitas terhadap harga saham.

4. DPR mampu memoderasi pengaruh CR terhadap harga saham pada model penelitian yang terbentuk.

5. DPR tidak mampu memoderasi pengaruh DER terhadap harga saham pada model penelitian yang terbentuk.

\section{DAFTAR PUSTAKA}

[1] Amanda, W. B. B. A., \& Pratomo, W. A. (2013). Analisis Fundamental dan Resiko Sistematik Terhadap Harga Saham Perbankan yang Terdaftar Pada Indeks LQ 45. Ekonomi dan Keuangan, 1(3).

[2] Antara, I. M. J. (2012). Pengaruh Dividend Payout Ratio, Price to Book Value Ratio, dan Price to Earnings Ratio pada Return Saham di Bursa Efek Indonesia Periode 2009-2011. E-Jurnal Akuntansi.

[3] Ariyani, L., Andini, R., \& Santoso, E. B. (2018). Pengaruh Eps, Cr, Der Dan Pbv Terhadap Harga Saham Dengan Kebijakan Dividen Sebagai Variabel Intervening (Studi pada Perusahaan Manufaktur yang Terdaftar di BEI Tahun 2011-2015. Journal Of Accounting, 4(4).

[4] Asmirantho, E., \& Yuliawati, E. (2015). Pengaruh dividen per share (DPS), dividen payout ratio (DPR), price to book value (PBV), debt to equity ratio (DER), net profit margin (NPM) dan return on asset (ROA) terhadap harga saham pada perusahaan manufaktur sub sektor makanan dan minuman dalam kemasan yang terdaftar di BEI. JIAFE | Jurnal Ilmiah Akuntansi Fakultas Ekonomi, 1(2), 95-117.

[5] Brigham dan Ehrhardt. (2011). Financial Management:Theory \& Practice. Edisi ke $13^{\text {th }}$. USA: South-Western Cengage Learning.

[6] Brigham dan Houston. (2017). Fundamentals of Financial Management. Edisi ke $9^{\text {th }}$. USA: South-Western Cengage Learning. 
[7] Christopoulos, A., Vergos, K., \& Mylonakis, J. (2008). How Stock Prices React to Managerial Decisions and Other Profit Signaling Events in the Hellenic Mobile Telecom Market. Journal of Money, Investment and Banking, (2), 37-47.

[8] Darnita, E. (2014). Analisis Pengaruh Return On Assets (ROA), Return On Equity (ROE), Net Profit Margin (NPM) Dan Earning Per Share (EPS) Terhadap Harga Saham (Studi Pada Perusahaan Food Dan Beverages Yang Terdaftar Di Bursa Efek Indonesia (BEI) Pada Tahun 2008-2012). Fakultas Ekonomi dan Bisnis Jurusan Manajemen Universitas Dian Nuswantoro Semarang.

[9] Dewi, P. D. A., \& Suaryana, I. G. (2013). Pengaruh EPS, DER, dan PBV Terhadap Harga Saham. E-Jurnal Akuntansi, 215-229.

[10] Gibson. (2013). Financial Reporting Analysis $13^{\text {th }}$ edition. South Western:Cengage Learning

[11] Hardaningtyas (2014). Pengaruh Faktor Fundamental Mikro Makro Terhadap Harga Saham Perusahaan Semen Go Public. Jurnal Ilmu \& Riset Management. 3(10)

[12] Horne et,al (2005). Prinsip-prinsip Manajemen Keuangan. Jakarta:Salemba Empat

[13] Hussein, Ananda Sabil. (2015). Penelitian Bisnis dan Manajemen Menggunakan Partial Least Squares (PLS) dengan SmartPLS 3.0. Malang:Universitas Brawijaya.

[14] Hutabarat, A. S. (2020). Willingness to Pay Untuk Konservasi Spesies Terancam Punah Di Taman Nasional Gunung Halimun-salak: Aplikasi Metode Contingent Valuation: Willingness to Pay for the Conservation of Threatened Species in the Halimun-salak Mountain National Park: Contingent Valuation Method Application. Jurnal Ekuilnomi, 2(2), 102-115.

[15] Indonesian Stock Exchange. Laporan Keuangan dan Tahunan. $<$ http://www.idx.co.id/id$\mathrm{id} /$ beranda/perusahaantercatat/laporankeuangandantahunan.asp $\mathrm{x} \geq$

$<$ http://www.idx.co.id/id-

id/beranda/publikasi/ringkasankinerjaperusahaantercatat.aspx $\geq$

[17] Ismail, F., \& Yahya, Y. (2018). Pengaruh Current Ratio, Earning Per Share Dan Return On Asset Terhadap Harga Saham. Jurnal Ilmu \& Riset Manajemen, 6(10).

[18] Kahfi, M. F., Pratomo, D., \& Aminah, W. (2018). Pengaruh Current Ratio, Debt To Equity Ratio, Total Assets Turnover Dan Return On Equity Terhadap Nilai Perusahaan (Studi Kasus Pada Perusahaan Manufaktur Sektor Food And Beverage Yang Terdaftar Di Bursa Efek Indonesia Pada Tahun 2011-2016). eProceedings of Management, 5(1).

[19] Martini, P. D. (2015). Pengaruh Kebijakan Utang dan Profitabilitas Terhadap Nilai Perusahaan: Kebijakan Dividen sebagai Variabel Pemoderasi. Jurnal Ilmu dan Riset Akuntansi, 3(2).

[20] Mery, K. N., \& Kurnia, P. (2017). Pengaruh Likuiditas, Leverage Dan Profitabilitas Terhadap Nilai Perusahaan Dengan Kebijakan Dividen Sebagai Variabel Moderasi Pada Perusahaan Pertambangan Yang Terdaftar Di Bursa Efek Indonesia Tahun 2011-2014. Jurnal Online Mahasiswa (JOM) Bidang Ilmu Ekonomi, 4(1), 2000-2014.

[21] Meythi, et,al. (2011). Pengaruh Likuiditas dan Profitabilitas Terhadap Harga Saham Perusahaan Manufaktur yang Terdaftar di Bursa Efek Indonesia. Jurnal Bisnis Manajemen dan Ekonomi, 10(2), 2671-2684.

[22] Morningstar. Independent Investment Research. < https://www.morningstar.com/>

[23] Mulyana, M., Hakim, D. B., \& Hartoyo, S. (2020). Entrepreneurial Activities And Performance Of Rice Farming In Bojongpicung Sub-District, Cianjur Regency. European Journal of Molecular \& Clinical Medicine, 7(3), 4528-4535.

[24] Munawaroh, A. (2015). Pengaruh Profitabilitas Terhadap Nilai Perusahaan Dengan Corporate Social Responsibilty Sebagai Variabel Moderating. Jurnal Ilmu dan Riset Akuntansi, 3(4). 1-17. 
Stocks Price and Dividend Policy in LQ45 Companies

150
[25] Purba, J. H. V., Ratodi, M., Mulyana, M., Wahyoedi, S., Andriana, R., Shankar, K., \& Nguyen, P. T. (2019). Prediction Model in Medical Science and Health Care. International Journal of Engineering and Advanced Technology, 8, 815-818.

[26] Rahmawati, D., \& Suryono, B. (2017). Pengaruh DPR, EPS Dan DER Terhadap Harga Saham. Jurnal Ilmu dan Riset Akuntansi, 6(6).

[27] Sholihin, Mahfud., Ratmono, Dwi. (2013). Analisis SEM-PLS dengan WarpPLS 3.0. Yogyakarta:Andi.

[28] Solimun, et,al. (2017). Metode Statistika Multivariat Pemodelan Persamaan Struktural (SEM) Pendekatan WarpPLS. Malang:Universitas Brawijaya Press.

[29] Sondakh, F., Tommy, P., \& Mangantar, M. (2015). Current Ratio, Debt to Equity Ratio, Return on Asset, Return on Equity Pengaruhnya Terhadap Harga Saham Pada Indeks Lq 45 Di Bei Periode 2010-2014. Jurnal EMBA: Jurnal Riset Ekonomi, Manajemen, Bisnis dan Akuntansi (ISSN 2303-1174). 3(2), 749-756. 